\title{
Rural development and women's liberation: caste, class and gender in a grass-roots organisation in Tamil Nadu, South India
}

\author{
Burnad Fatima
}

Organising the Rural Poor: caste and class In 1974 six young graduates of village Harijan background who wanted to dedicate their lives to the rural poor got together to try to start a mass movement in Tamil Nadu, South India. Some were from Christian families and had studied in Christian schools; all had training in community organising. Since Harijans were the most oppressed and made up the majority (68 per cent) of the population of Chingleput district where we began our work, we initially organised the poor and landless along caste lines. Our work was successful; in 1977 we formed an association with 3,000 Harijan members.

Who are the Harijans? The name, given by Mahatma Gandhi, means 'Children of God'. Descended from the original population of India, today they are landless and 'untouchables'. Although the government has passed anti-discriminatory legislation recognising their equal citizenship and certain land and other rights, these changes have not been carried out, and landlords preserve many social customs aimed at humiliating the Harijans. For example, when landlords give food or water to Harijans they insist that it must be received in bare hands, without a plate or a cup. Landlords do not allow Harijans to enter their homes or to draw water from community wells. They feel insulted if a Harijan appears in anything but the most abject poverty: any Harijan fortunate enough to own a bicycle must not ride it through the landlords' streets; if a Harijan man wears sandals or a shirt he must remove them in the presence of a landlord and stand before him barefoot and bare chested. Harijans daring to defy these customs, or to ask for their legal rights, can be beaten or have their homes burned down, or even be burned alive. After they formed an organisation, however, Harijans found they were more secure and less vulnerable to such attacks.

In 1977, after the movement was well established in one district, the organisers, or animators as we call ourselves, went individually to the poorest villages in
Tamil Nadu. Some of us returned to our own native villages. At this point we changed to organising on a class basis, forming Landless Labourers' Associations (Vivasaya Cooligal Iyakkam) which include landless of other castes as well as Harijans. These associations were officially recognised and formally registered under the Societies' Registration Act. By 1981 we had 15 well-trained animators, each in charge of a Landless Labourers' Association of over 3,000 members, working full-time in five districts: North and South Arcot, Chingleput, Madurai and Sathyavedu. The animators do not control these organisations, rather they are consulted in time of need.

\section{Education for Development}

The name of my organisation in North Arcot district is Society for Rural Education and Development. The words education and development mean different things to different people. For us, development is not about material things but about human beings. As Julius Nyerere said, to develop people is not like building roads or wells; people cannot be developed $b y$ others, they must develop themselves. Development occurs when people understand the oppressive conditions in which they live and act to change them. We aim at the total development of each individual's social opportunities, economic security and political freedom. To achieve this we start from each individual's own situation and get him or her to ask such questions as: 'Why am I like this? What made me like this? What can I do to change my situation?'

Instead of providing an answer for the problems of the poor, schools train them to accept their condition rather than try to change it. An authentic education would teach people how to liberate themselves from oppression. We also believe it is better to educate people about their own lives rather than giving economic aid or handouts. We often repeat the saying: 'Give me a fish, I eat for a day; Teach me to fish, I live for a lifetime'. Doling out material goods in economic 
programmes makes people dependent, turns them into beggars and takes away their dignity.

Our method of work is to discuss everyday situations with the villagers. We developed our methods of organising by learning from various writers, including Paulo Friere, Mahatma Gandhi and Saul Alinski. Our educational programmes are based on Paulo Friere's concept of consciousness-raising, or 'conscientisation'. This method combines problem-posing and literacy teaching in street-corner classes in the villages. Gandhi's concept of education for liberation has also been adopted to teach community spirit to good village leaders. In community organising we use Saul Alinski's methods for building people's self-confidence and power. We analyse the social and political power structures in each village through informal discussions with people.

Although we work with the concept of 'conscientising', we have modified Paulo Friere's methods. For instance, in conducting literacy classes we encountered many difficulties. Friere says it is possible to teach the illiterate to read and write within 45 days. This may be true for other languages and cultures, but was not so in our case. The villagers showed a lot of interest at the beginning but quickly became more interested in discussing the issue of caste discrimination against Harijans than in learning to read and write. We added new methods to those suggested by Friere. In consciousness-raising we make great use of songs, stories related to local problems, proverbs, spontaneous street theatre, acting out, imitating the local rich, etc. Our biggest problem with 'conscientisation' was that the people were already very aware of their oppression, and after discussing their problems wanted to move to direct action right away before enough people were organised to support them and make it a successful mass movement.

\section{Women: a special case?}

Caste differences used occasionally to cause some problems in organising the landless to work together. For example, when association members came from distant areas to a long meeting, we had to organise food; sometimes caste Hindus did not want to eat with Harijans. However, the major difficulty we encountered in the initial years was the low level of women's involvement in the movement and men's reluctance to let women attend meetings at all. Before we began our work, women were not allowed to attend village meetings on any matter as men considered it disrespectful for women to want to come to meetings. If they tried to attend, the men shouted at them and sent them home.

In the beginning, while organising the landless labourers, women's issues were not given importance.
Therefore, we have started organising the rural women's liberation movement as a separate organisation for the time being.

Our society is male dominated and patriarchal; women are oppressed in many ways as daughters, wives, mothers and widows. According to the Hindu religion women are to be obedient to father, husband, and son. There are many taboos, proverbs, poems, expressing social attitudes towards women. For example: a girl is not even supposed to laugh, this is considered unchaste and immodest. Women are considered untrustworthy: 'Believe a mad elephant or a snake but never a woman'. Women are taught that 'even if your husband is a stone or a blade of grass you have to worship him'.

All the housework is done by women. Every day she has to get firewood and buy cooking oil and other necessities, whereas the men have more freedom to spend their wages as they like, to drink, play cards and to smoke. Women are criticised if they ever spend money on themselves, and are considered to be fully responsible for their family's welfare. Education is given only to sons, not to daughters, who will one day marry and leave the parents' house; as a result many women are illiterate. Their economic contribution is not recognised. Women are regarded as 'dependent', which is not true, since the whole family - as well as the society - is dependent on them.

Mortality rates are very high among women, from the cradle. Due to prejudice against daughters, many girl babies are killed at birth while others suffer neglect and high mortality. Women are not taken care of during pregnancy but make great sacrifices to feed and look after their families and neglect their own welfare. While women suffer as daughters and as wives, the fate of the widow is worst of all. According to the old Hindu tradition of sati the widow was encouraged to burn herself on her husband's funeral pyre. While this practice was abolished during the colonial period there have been some cases in India in recent years which, along with the dramatic rise in burning to death of young brides because of insufficient dowries, is very worrying, and we are afraid such atrocities might spread to our area.

A widow is supposed to sacrifice all happiness: she must never again wear jewellery, flowers or colourful clothes. She is not allowed to remarry or to have sexual relations, which is particularly hypocritical as in fact widows are often sexually exploited.

Harijans and other landless women suffer as women as well as because of their caste and class. Harijan women are paid particularly low wages, although they work very hard, and in some areas they are experiencing 
increasing difficulty in finding paid agricultural work as, due to mechanisation, unemployed men are replacing them. Harijan and other women agricultural labourers are of ten sexually exploited by landlords.

\section{Organising a Rural Women's Liberation Movement}

In our attempt to build up and st rengthen the landless labourers' movement we found it was necessary to organise separate women's meetings around women's issues. We now hold combined meetings as well as separate meetings for men and women. In the women's meetings we began by discussing the special oppression of rural Harijan women. We soon had a particularly horrible woman's issue to discuss and to try to act upon.
Nagomi, a mother with three children, was beaten by the landlord while collecting firewood. She kept silent for several days, afraid to talk about it. When it became known, the women went up to the Harijan welfare minister during a public meeting and made him step down from the stage to listen to their protest. The landlord was arrested. Nagomi refused to compromise with the landlord at the police station, and demanded that he apologise in the village. He was brought to the village where he apologised with a written statement.

During our women's meetings, we found that women were interested in solving village as well as women's issues. For example, in 1981 women organised to meet the thasildar (a government official) to request that a road be built from their village to the drinking well. In

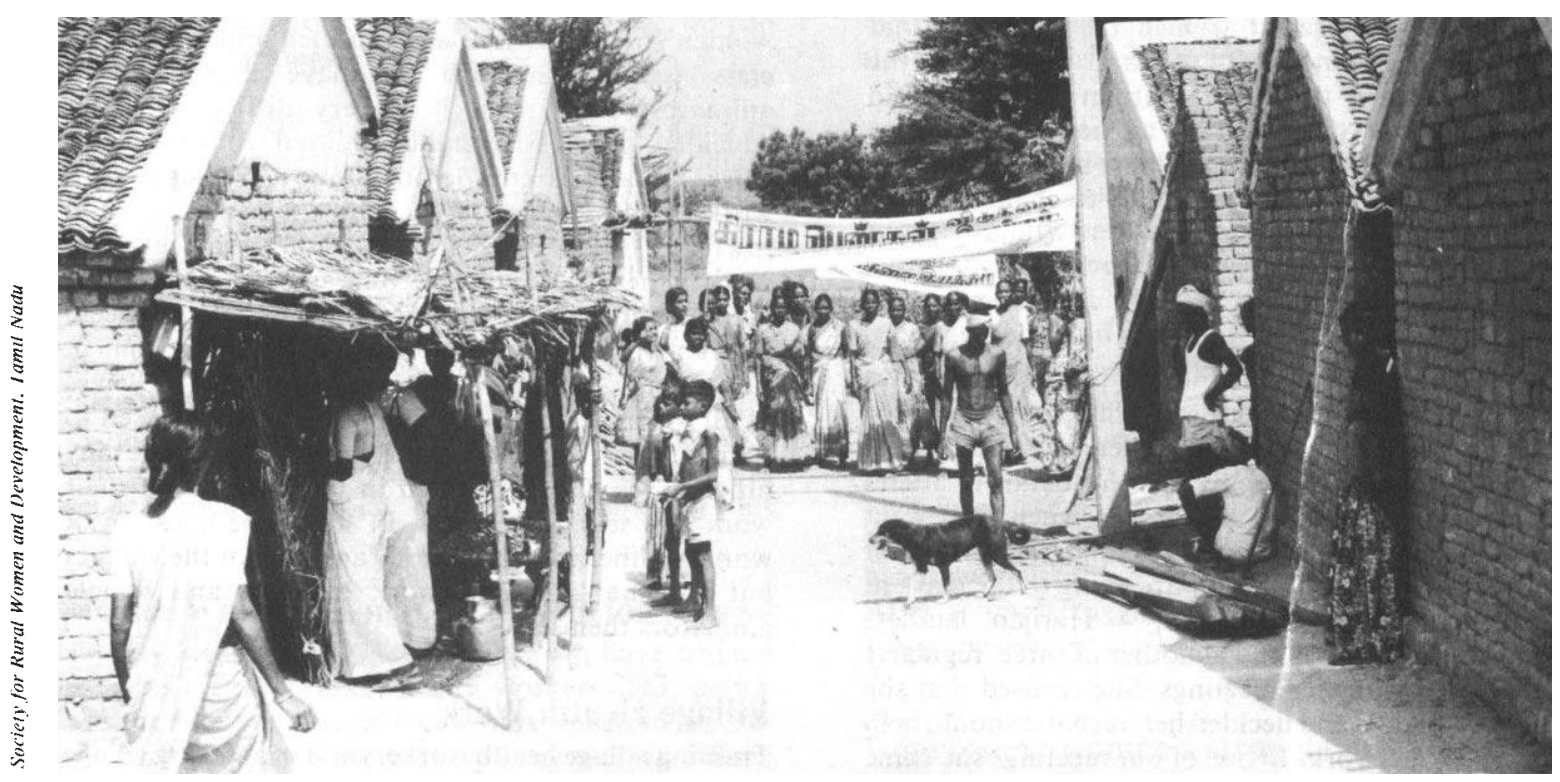

A march of the Rural Women's Liberation Movement

On 24 December 1980, an 11 year old schoolgirl named Suganya was attacked while she was playing with friends. She was raped and stabbed in 21 places; she had to be hospitalised and required intensive care for her injuries. Although everyone knew who the rapist was, the police did not arrest him because he was an important person locally in the ruling political party. Our women's meeting discussed the issue and organised a protest rally. Although we were not given permission to hold the demonstration, we went ahead, and 2,000 women from neighbouring villages participated, ready to risk arrest to protest against the state government's handling of the case. Everyone was very surprised at the spontaneous participation of such a large number of women at very short notice to protest against this rape. the past only men went to the higher government officials to request basic amenities. I was surprised at the way women questioned the thasildar and I believe the men too were surprised. On another occasion, when a revenue inspector visited the village to mark the route for a new link road, the men agreed to his proposed sketch. But the women did not agree and wanted it to be redrawn to fit the people's needs. The revenue inspector was shocked to see women making demands and enquired who they were. He was told "those women are from the sangam (the women's movement) that is why they are "talking" and "demanding"". 
Once mobilised, the village women are very bold and creative in taking action to change their world. For example, the women's meeting decided to organise women to draw water from a village pond where Harijans were not allowed to take water. This pond was supposed to be for the use of everyone in the community as the government had spent money on deepening and cleaning it, but the high caste Hindus kept it for themselves, and refused to allow Harijans to draw water from it. When the Harijans went to the pond they had to wait until a caste Hindu fetching water from the pond would pour some water into the Harijan's pot. The Harijan women protested repeatedly and were very upset that after repeated negotiations there was no change. They decided to take direct action by going to the pond in a large demonstration. As a protest against prejudices against their caste and against women they planned that menstruating women would draw water from the pond first, then the other Harijan women would follow. Neither menstruating women nor Harijans should be considered unclean; these are two insulting taboos which our women now dare to challenge.

At first men interfered with our women's meetings and scoffed, citing such proverbs as 'The day breaks only when a cock crows, not when a hen squawks'. Many members were forbidden by their husbands to attend the women's meetings, and beaten when they went anyway. But the women kept coming; they got out of the house by saying that they are going to the market. One such woman, Chandra, a Harijan landless agricultural labourer and a mother of three, regularly attends our women's meetings. She realised that she was overworked and decided her husband should help with the housework. In one of our meetings she came to the front and told everyone that she had talked her husband into fetching water from the well for the first time in her family or the village's history. Another woman, Govindammai, then challenged the others, saying that she was willing to pay RS 100 to any woman who could make her husband clean the area in front of the house with cow dung, a job women must do every morning. When we raised the idea of men helping to relieve women's overwork in the house in our combined meetings the men did not like the idea. They said that we were trying to create problems. One of our village leaders was so disturbed that he could not sleep. In the early hours of the morning he sat up in bed asking himself: 'What is all this about? What is women's liberation? Are women not free?' He was really puzzled by these new ideas. Our women realise that if they want men to share the housework there will be some disturbances at home, but they are ready to face this.

\section{The Women's Training Centre and the Formation of Animators}

We have also set up a training centre for women where school drop-outs and women who cannot do agricultural work are given opportunities to be economically independent. This centre teaches women tailoring, embroidery and needlework: embroidery is done on various items of men's and women's wear and sold locally as well as exported. Women are also trained in practical matters including health, hygiene, kitchen gardening and poultry rearing. Some women who began as trainers or trainees at the centre were later sent to the villages for training as animators of the landless labourer's movement.

In the Society for Rural Education and Development both women and men animators organise women on women's issues as well as both men and women on class issues. Although we have more women animators than men, it is very difficult to find educated, progressive and committed women for this work. Usually parents do not allow their daughters to work in the villages. They send them to cities and towns in search of better jobs rather than let them work in the remote villages. Male animators cooperate with us in organising women, but of ten do not seem fully convinced of the importance of liberatng women. For example, once we organised a meeting of the wives of all the male animators. We were very surprised to find out that their husbands treated them like any other wives and kept them in the dark about their work and social problems. In short, the question of women's liberation is not only an issue for the villages but for the lives and work of male and female animators themselves.

\section{Village Health Work}

Training village health workers and sponsoring village health programmes is another important aspect of our education and organising programme. Our health work includes education on nutrition, sanitation and cleanliness in the villages. We regard an unbalanced diet as a main reason for widespread illness. Landless villagers cannot buy good nutritious food with their low wages. While teaching them nutrition through flash cards, drama, songs and stories we do not advise them to eat expensive foods such as eggs, fish or Horlicks, but rather tell them about the nutritious value of locally grown greens, pulses and grains. We criticise local superstitions against nutritious food such as papayas, greens, groundnuts and raggi. If these are not available we buy seeds and urge women to plant them near their houses where they can water them every day.

Regarding hygiene, we cannot advise women to bathe every day and dress in good clothes. Instead, we advise 
them to cover food, to boil water, to drive away cats and dogs while eating, to keep the cowshed next to the house clean, to tether cows and goats away from their sleeping place and to prevent water stagnation and so on. We follow through to see whether they can carry out the advice, and help them. Through health education we also make people aware that ill-health is due to poverty, and point out the necessity of fighting exploitation.

For common illnesses such as diarrhoea, colds and coughs we urge villagers to use the traditional home remedies which they know better than any of us. Villagers prepare a decoction out of pepper and ginger for colds and coughs which is much better than any commercial cough syrup. For diarrhoea we recommend burnt rice - ie, charcoal. We have collected home remedies and herbal medicines from village women during our meetings.

The villagers have learned to organise politically to fight for better health care. For example, in a village called Palliyankup Pam, many families were affected by a severe viral fever which was spreading rapidly. With the help of the village health worker the villagers reported this to the nearby primary health centre, but the doctor in charge refused to attend to the problem immediately. The villagers then decided to send telegrams to the District Health Office and to relevant people in the Health Department. The next day a district medical team arrived and the doctor was reprimanded in front of the villagers for his negligence.

\section{Health Workers: a new social role for widows}

To give widows a new social role, we have trained some of them as village health workers. This policy was the result of a tragic incident. A widow in her late thirties came for help to two young women village health workers in our organisation. She did not name her problem clearly but said that she "had not bathed for two months', a euphemism used in our language to refer to missing menstrual periods. The inexperienced young health workers, not understanding, sent her away with some asprin. A few days later we heard the drum beatings which announced a death. When we enquired, we learned that the widow had hanged herself out of fear of a hostile social reaction in the village when her pregnancy became visible. After this incident we paid special attention to widows, training several as health workers, and helped pregnant women with check-ups, nutrition, etc. The widows in the women's movement have been trained as 'bare-foot doctors' and birth attendants; each has a kit including everything needed during the delivery of a child. Traditionally, widows were considered to bring bad luck and infertility and therefore not allowed to conduct deliveries. The women's movement has created a new image; the villagers have forgotten that the health workers are widows but call them 'sisters' or 'teachers' instead of widows. They play an important role as health workers and are also responsible for other activities of the movement which adds to their self-confidence, social recognition and respect.

We started health programmes as an entry point for involving women and forming more women's movement branches in the villages. Village health workers are selected by the community, especially the women, along with animators. We no longer train young unmarried girls since several have had to leave the movement and the area because of marriage. We prefer to train married, middle-aged women with some educational background. Without the burden of young children, they are free enough to attend our meetings frequently, carry out their work well and win the acceptance of the whole village.

At a women's meeting in one village, a woman named Bakkiam was selected for training to be the village health worker. Bakkiam belongs to a Dhoby caste: she and her family wash clothes for the whole village. In return they are given food every night and paid in kind after the harvest. All the women liked Bakkiam, because she is kind and hard-working. But the elderly village leader objected because she belonged to the Dhoby caste, which is lower than the Harijans. One woman protested to this male village leader saying: 'When you meet at the centre of the village to decide on village issues, have you ever consulted women? Why should you be consulted while selecting a village health worker? It is a women's issue. Please go away'. After a long struggle Bakkiam was trained to be a village health worker.

\section{Conclusion: women's struggle and class struggle}

Many more incidents could be recounted but what is more important is what we can learn from them. When women are united and given opportunities, they are very capable and very militant. After working with women for several years I am convinced that women should be organised separately on women's issues. However, this question is still much debated within our organisation. Many male animators have begun to organise separate women's meetings, but some have argued that only class issues should be discussed. From time to time I think that perhaps our women's movement should concentrate on fighting for equal distribution of land and for equal wages. Certainly when we touch on issues concerning the role of women in the family we face a lot of problems. Recently the husband of one leader of a village woman's movement threatened to divorce her because of her involvement in the movement. Divorce, or even separation creates 


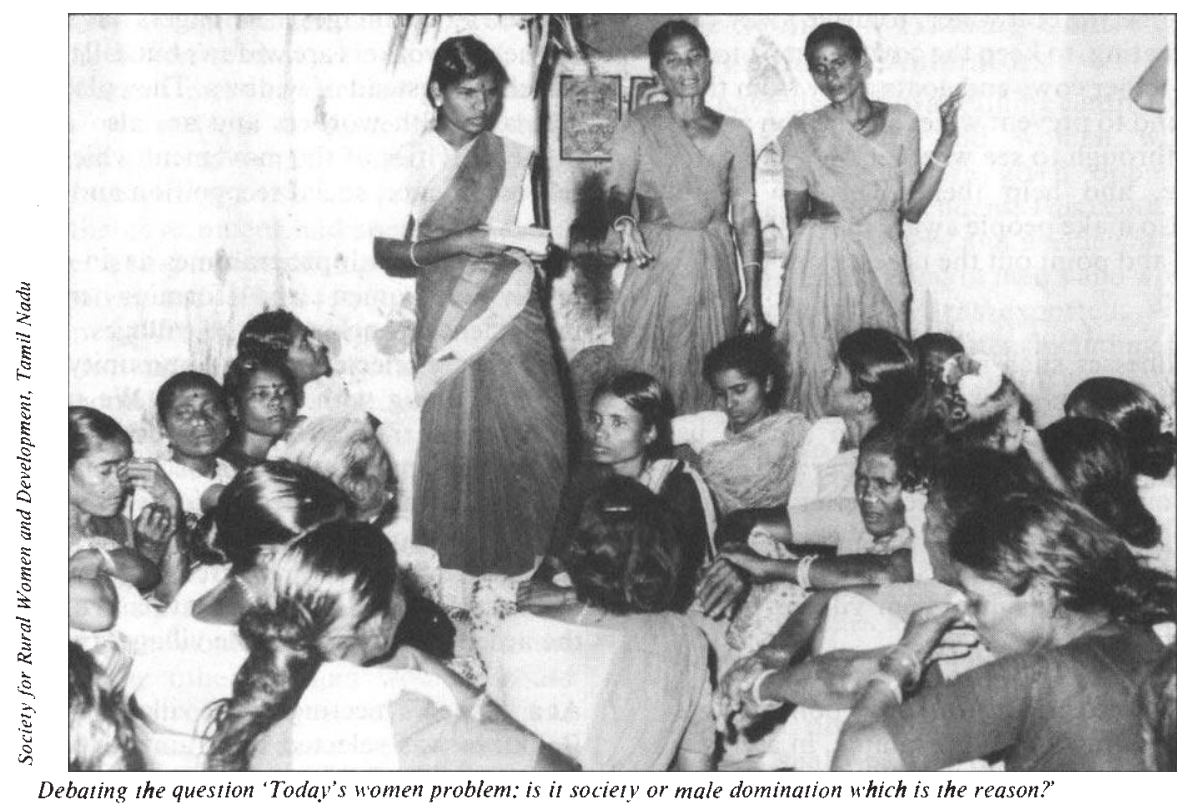

impossible problems for women, because in our society women are not allowed to live alone.

However, the women's issues within our society, difficult as they are to solve, must be faced and not avoided. The women's movement should not neglect to organise women on women's issues such as rape, dowry, wife beating, obscene pictures and advertisements, etc. The women's movement should try to motivate women to change the specific roles given them at home. We should motivate our family members to share the household burdens equally by creating collective responsibility because the house and the family belong to everyone. Women from different backgrounds should get together and help each other to fight against oppression. When people identify similar oppression, comparing it helps them to speak about it and they are strengthened. Taking up women's issues is an opportunity for raising women's social consciousness, and provides an opportunity for many women to come out of their shells. Once women are organised separately they become more active in the class movement than before.

I will end with one final example. On 8 March 1983, International Women's Day, the Rural Women's Liberation Movement of Arakkonam district, Tamil Nadu organised a programme including a march, debate, cultural programme and mass meeting attended by men and women. The day began with a march of more than 500 women to Kilandur village where two women had recently been beaten up by village goondas (thugs). The women carried banners and shouted slogans regarding women's issues. After the demonstration the programme continued at the Rural Service centre in Ulliambakkam village. A debate was held, with both men and women speakers, on the theme: 'Today's Women Problem: Is it Society or Male Domination which is the Reason?' The conclusion was that we should fight against both male domination and social injustice. This was followed by a mass meeting at which representatives from various organisations in the district, both men and women, denounced atrocities against women in our society. The day ended with a play about the dowry issue performed by the Rural Women's Liberation Movement.

Such programmes help women to come out of their villages, to meet other women and listen to their problems. Neither women's problems nor social problems can be solved as long as women remain isolated in their own homes. Men's attitude toward women changes when they begin to realise that women's role is not only to do the cooking but also to participate in social movements. The traditional roles which draw a line between men and women are gradually removed as women come forward and prove their worth to men as public speakers and activists.

The integration of the women's movement and the landless labourers' struggle will become a broad people's movement to fight against oppression in society. We must continue to educate, train and organise women to fight against their own oppressions and the oppressions of others to achieve a new, just, society where everyone, irrespective of sex, class or caste, is equal. 